THOMAS WILLIAM ROBERT LYNSKEY

\title{
UNSUBSTANTIATED REPRESENTATIONS: AN UNSUBSTANTIATED REFORM?
}

Submitted for the LLB (Honours) Degree

Faculty of Law

Victoria University of Wellington

2014 


\begin{abstract}
This essay analyses the recent amendment to the Fair Trading Act 1986 that created a prohibition of "unsubstantiated representations" in trade. The reform process presented an opportunity to bring the FTA in line with recent amendments to the Australian law that had addressed the same issues. However, New Zealand opted to go further. This essay traces the prohibition through the wider consumer law reform process to investigate how the final provision was arrived at. By critically analysing the process that led to the amendments, the essay suggests that the decision to create a prohibition was based on flawed reasoning. In particular, it is argued that New Zealand should have followed the Australian approach, and that creating a prohibition has instead produced unnecessary liability in the absence of sufficient justification.
\end{abstract}

Key words: Fair Trading Law; Unsubstantiated Representations; s 12A Fair Trading Act 1986.

\title{
I Introduction
}

In 2005, the Ministry of Consumer Affairs commenced a review of New Zealand's consumer protection laws. The review sought to revise, inter alia, the Fair Trading Act 1986 (the "FTA") in the light of changes that had occurred in the market place over the preceding twenty years. Several problem areas were highlighted. One of the most significant was that, due to the cumbersome nature of the existing enforcement mechanisms in the Act, it appeared that traders were able to make unsubstantiated claims with relatively little fear of prosecution.

Australia had recently addressed this issue and responded by empowering their regulatory agency to issue "substantiation notices". The Ministry's review initially followed the Australian approach. However, it was eventually abandoned in favour of a general prohibition of unsubstantiated representations in trade.

This essay will track the development of the Ministry's review in order to demonstrate how and why this approach was adopted. In doing so, it will argue that the decision favouring a general prohibition was based on flawed reasoning, and that it 
created unnecessary liability. It will be submitted that aligning the FTA with the Australian provisions would have achieved the desired policy outcomes.

The essay will further argue that the need for a general prohibition was not convincingly demonstrated. Accordingly, it will suggest that the real motivation for creating a prohibition was to shift the cost of substantiating claims from the Commerce Commission onto traders. The essay will conclude that, in the absence of compelling evidence to justify this move, the prohibition of unsubstantiated representations therefore amounted to an unsubstantiated reform.

\section{The FTA, Commerce Commission and Misrepresentations}

New Zealand's FTA was the implementation of a 1984 election promise to reform consumer laws and stamp out insidious trade practices. ${ }^{1}$ In a trade environment where the recent release of the Commerce Act 1986 sought to increase competition, it was thought that the FTA would perform a complementary role by protecting the interests of consumers. ${ }^{2}$ Accordingly, it contained a range of general and specific prohibitions of misleading and deceptive conduct in trade.

Section 9 of the FTA reads:

\section{Misleading and deceptive conduct generally}

No person shall, in trade, engage in conduct that is misleading or deceptive or is likely to mislead or deceive.

Contravention of s 9 attracts civil liability. The provision is deliberately broad to allow a wide variety of misleading conduct to be targeted. The Supreme Court has described the section as "directed to promoting fair dealing in trade by proscribing conduct which, examined objectively, is deceptive or misleading in the particular circumstances."3

Sections 10-14 are narrower, and contain prohibitions of specific instances of misleading conduct and false or misleading representations. Contravention of those

Lindsay Trotman Misrepresentation and the Fair Trading Act (Dunmore Press, Palmerston North, 1988) at 1.

2 Trotman, above n 1, at 1.

3 Red Eagle Corporation Ltd v Ellis [2010] NZSC 20 at [28]. 
sections attracts criminal liability, therefore a higher burden of proof rests on the prosecuting party.

Due to the wide scope of s 9, any conduct that contravenes ss $10-14$ will also be caught by s 9. Indeed, Lindsay Trotman described ss 10-14 as "[containing] no more than specific examples of conduct within the wide and general terminology of s 9."4 A false representation, or "misrepresentation", then, is the paradigm example of misleading or deceptive conduct.

While consumers and corporations can bring private actions under the FTA, ${ }^{5}$ the Commerce Commission is the primary regulatory agency charged with monitoring and enforcement of the Act. ${ }^{6}$ The Commission has authority to bring prosecutions for contraventions of the Act, ${ }^{7}$ and it may also apply to the court for an injunction to restrain a person from engaging in conduct that would contravene s $9 .{ }^{8}$

\section{A Misrepresentations}

Prior to the 2014 amendments, if the Commission suspected that a trader had no basis for a claim that they had made about goods or services, it would usually have to prove that the claim amounted to an actionable misrepresentation.

A misrepresentation is a statement of past or existing fact that is false. It is to be distinguished from a promise to do something in the future that induces entry into a contract. It is also to be distinguished from a statement of opinion. However, a statement of opinion may, under certain circumstances, amount to an actionable misrepresentation.

In Esso Petroleum Co Ltd v Mardon, ${ }^{9}$ the plaintiff oil company interviewed $\mathrm{Mr}$ Mardon, a prospective tenant of a petrol station that Esso had constructed. In the course of negotiations, Esso gave Mr Mardon an estimate that the throughput (turnover) of the station would reach 200,000 gallons per year. It was found by the trial judge that $\mathrm{Mr}$

Trotman, above $\mathrm{n} 1$, at 5 .

Fair Trading Act 1986, s 41.

Ministry of Consumer Affairs Consumer Law Reform: A Discussion Paper (June 2010) at 12.

Lindsay Trotman and Debra Wilson Fair Trading: Misleading or Deceptive Conduct (LexisNexis, Wellington, 2006) at [1.8].

$8 \quad$ Fair Trading Act 1986, s 41(1)(a).

$9 \quad$ Esso Petroleum Co Ltd v Mardon [1976] QB 801. 
Mardon entered into the tenancy agreement with Esso in reliance on that estimate. ${ }^{10}$ While the estimate may originally have been accurate, Esso failed to adjust it following changes made during construction of the station. It was therefore significantly overstated.

At the High Court and at the Court of Appeal, Mr Mardon argued that Esso should be liable in tort for negligent misrepresentation. The problem that confronted Mr Mardon was that the estimate of throughput was not a statement of past or existing fact, but rather a statement of opinion or forecast. Nevertheless, the Court of Appeal held that because Esso possessed special skill and knowledge in making such estimates, the forecast carried an implied statement of fact that there were reasonable grounds to believe it was accurate. $^{11}$

Because Esso had acted negligently, and no such reasonable grounds existed, the company was liable for negligent misrepresentation.

\section{B Justification}

The justification for prohibiting misrepresentations and misleading or deceptive conduct is unexceptionable. The Ministry of Consumer Affairs has stated that: ${ }^{12}$

Misleading and deceptive conduct and false representations are regarded by society as unjust and unacceptable. Such conduct can lead to detriment for consumers and honest businesses, can distort markets, and lead to breaches of contract. This then has the impact of reducing confidence in the market and reducing competition, leading to associated negative economic impacts.

So much for misrepresentations. Before turning to the recent amendments, it will be helpful to place the above provisions in context by briefly outlining the facts of a significant case prosecuted by the Commerce Commission.

\section{Probitas Fertiliser - a Case Study}

Mr Ewan Campbell was a lay litigant, a self-professed "kiwi bloke" and, if his advertisements were to believed, the inventor of a revolutionary organic fertiliser.

\footnotetext{
$10 \quad$ Esso Petroleum Co Ltd v Mardon [1975] QB 819 at 824.

11 Esso, above n 9, at 819.

12 Ministry of Consumer Affairs, above n 6, at 27.
} 
Mr Campbell operated a lucrative business selling his fertiliser "Probitas" at prices ranging from $\$ 300-\$ 350$ per tonne. The raw natural ingredients that made up the fertiliser ran to a cost of approximately $\$ 35$ per tonne. It was claimed that Probitas activated the electrical and magnetic processes in the target soil, thereby "unlocking" nutrients that would not otherwise be available.

Mr Campbell's happy enterprise hit a snag in 2003 when he approached Mr Sime, a dairy farmer, with an interest in purchasing lime and papa clay from him to use in the fertiliser. Mr Campbell left a pamphlet extolling the virtues of Probitas with Mr Sime. Mr Sime, however, was also a soil tester, and his son, Dr Sime, had a $\mathrm{PhD}$ in physical chemistry. Mr Sime consulted his son about the validity of the pamphlet's claims. Dr Sime doubted the various claims, and duly contacted the Commerce Commission. An investigation was then launched.

Four years later, the Commerce Commission obtained judgment in the Tauranga District Court against Probitas Ltd and Mr Campbell. ${ }^{13}$ Both the company and $\mathrm{Mr}$ Campbell personally were found guilty of multiple breaches of the prohibition of false or misleading representations in s 13 of the FTA.

Judge Callander delivered a colourful judgment. The Judge's preliminary observations included a lively passage on fair trading philosophy that is worth reproducing: ${ }^{14}$

The dualism of good and bad applies to inventors. There are the honest, sincere and proper innovators, genuinely trying to advance humankind. Then there are the swindlers, snake-oil salesmen, religionists, and pseudo scientists who part the naive from their money by scams, confidence schemes, and frauds. As the statesmanphilosopher Edmund Burke observed: "The credulity of dupes is as inexhaustible as the invention of knaves".

Probitas was fined $\$ 200,000$ and Mr Campbell was fined $\$ 60,000$. Costs of $\$ 12,499$ were also awarded against them. While the case involved a straight-forward application of $\mathrm{s} 13$, it was also a useful illustration of the evidential burden that rested on the Commerce Commission. To prosecute, the Commission was required to employ one Dr

13 Commerce Commission v Probitas Limited and Ewan Malcolm Campbell DC Tauranga CRN: 05079500275-82, 26 March 2007.

14 At [2]. 
Edmeades, a soil scientist, as an expert witness to produce sufficient evidence to prove beyond reasonable doubt that each of the claims made by the Company and Mr Campbell was in fact false or misleading. Mr Campbell did not testify, and produced no evidence regarding the scientific validity of his claims.

The preceding brief sketch of this case will serve as a useful reference point in the forthcoming discussion.

\section{Consumer Law Reform - Gaps in the Armoury? \\ A Finding an "initial thread"}

In July 2005, the Ministry of Consumer Affairs released an 'Initial Think Piece' outlining the scope of a review it was undertaking of New Zealand's consumer protection laws. ${ }^{15}$ The review sought to measure the effectiveness of the redress and enforcement provisions in the FTA against desired policy outcomes, and against overseas jurisdictions, in order to assess whether the laws ought to be amended.

In the Initial Think Piece, the Ministry made it clear that the measure of the effectiveness of consumer protection laws was the extent to which they achieved key policy outcomes. In particular, fair trading legislation must ensure that the reasonable expectations of consumers are met. ${ }^{16}$

To set the "Think Piece" cogs in motion, the Ministry explained the role of consumer protection legislation. By restricting the behaviour of traders, and providing for redress and enforcement provisions should those restrictions be disregarded, the goal was to create a competitive and fair trading environment wherein consumers could transact with confidence. This bedrock justification of the consumer protection legislation would persist through the future consumer law reform discussions, and find its way into the revised FTA under a brand-new purpose provision. ${ }^{17}$

The paper noted that regulatory design must contain penalties and enforcement mechanisms that achieve the objects of the legislation. It argued that an effective model

15 Ministry of Consumer Affairs Review of the Redress and Enforcement Provisions of Consumer

Protection Law: Initial Think Piece (July 2005).

16

At 2.

$17 \quad$ Fair Trading Act 1986, s 1A. 
for securing compliance should allow the regulatory agency access to a hierarchy of enforcement mechanisms. This hierarchy enables the agency initially to engage methods that persuade the trader to comply, while retaining the ability to escalate the sanctions if necessary. ${ }^{18}$

\section{B International Comparison}

In May 2006 the Ministry released an "International Comparison Discussion Paper"19 that sought to compare New Zealand's consumer protection laws against international consumer protection law standards. The motivations were consistent with those stated in the Initial Think Piece: fostering consumer confidence and developing competitive and fair markets.

By undertaking the international comparison exercise, the Ministry sought to identify consumer protection laws that were not in place in New Zealand, but whose inclusion would serve to promote consumer confidence, protect honest businesses, and assist the Commerce Commission in its role as New Zealand's regulatory agency. ${ }^{20}$

The paper proposed that amendments to the FTA be considered to provide for a number of new enforcement provisions. These provisions would "assist the Commerce Commission to act more effectively and efficiently", "allow [consumers] to transact with more confidence" and "enable compliant businesses to compete fairly." ${ }^{21}$ Importantly, the power to issue "substantiation notices" was included among the provisions.

The substantiation notice proposal derived from Australian legislation. Pursuant to state Fair Trading Acts, regulators had the ability to issue notices requiring traders to provide evidence capable of substantiating claims they had made about goods or services.

The availability of such powers in Australia was influential. This is unsurprising, since the development of New Zealand's consumer protection legislation has largely followed Australia's lead. Much of the Fair Trading Act 1986 was shaped from

\footnotetext{
$18 \quad$ At 4.

19 Ministry of Consumer Affairs Review of the Redress and Enforcement Provisions of Consumer Protection Law: International Comparison Discussion Paper (May 2006). 
provisions found in Australia's Trade Practices Act 1974. ${ }^{22}$ Furthermore, it was suggested that adopting substantiation notices would help promote the Government's Single Economic Market (SEM) agenda. ${ }^{23}$

However, there was another compelling reason to make such powers available. The paper noted that the FTA lacked a number of "mid-level" enforcement tools. Consequently, if the Commerce Commission wished to address a contravention of the Act, it had to go to court. The paper observed a claim by the Commission that over the preceding three years "the costs of litigation [had] trebled and the number of Fair Trading Act cases in the court system [had] doubled."24

Thus, another justification for the amendments emerged. In addition to fostering consumer confidence and creating an environment wherein honest traders could fairly compete, there was a desire to cut costs. As noted above, bringing a claim under the existing provisions placed the onus of proof on the Commerce Commission to demonstrate that claims made by the trader were in fact false or misleading. In the Ministry's own words: "In such instances, the Commission usually has to go to considerable expense and often has to employ significant resources in order to prove that such [claims] cannot be substantiated." 25

Whereas previous discussions led by the Ministry examined consumer protection laws in the light of consumer expectations and fair trading practice, this preliminary discussion of the adoption of substantiation provisions was couched in the language of efficiency. By shifting the onus of proof on to traders to substantiate their claims, the Commerce Commission would be spared the initial expense of disproving claims.

Seemingly as an afterthought, the Ministry stated that "[t]he ability of the Commerce Commission to issue substantiation notices should also encourage consumers to have greater confidence in the claims that are made about products or services." 26

\footnotetext{
22 Trotman, above $\mathrm{n} 1$, at 2.

23 The SEM agenda reflects an agreement between New Zealand and Australia to harmonise the regulatory requirements between the two countries to enable businesses, consumers and investors to conduct trans-Tasman operations.

$24 \quad$ At 23.

25 Ministry of Consumer Affairs, above n 19, at 33.

26

At 36 .
} 
Whether or not this cost-cutting attitude is objectionable per se, ${ }^{27}$ it does go some way toward explaining the eventual form the amendments took.

\section{Developments in Australia}

Shortly after the release of the International Comparison Paper, Australia made significant progress toward a unified national consumer law. It is helpful to set out briefly the Australian substantiation notice approach, as it provides a useful frame of reference for the general prohibition.

In 2008, the Australian Productivity Commission published a review of Australia's Consumer Policy Framework. ${ }^{28}$ A central aim of the review was to create a single national generic consumer law in Australia.

In the review, the Commission noted that the Australian Competition and Consumer Commission (ACCC), Australia's national regulator, had voiced complaints about the narrow scope of their information-gathering powers under the relevant fair trading legislation. ${ }^{29}$ The complaints echoed the New Zealand Commerce Commission's own concerns regarding their information-gathering powers, which are discussed below.

The Productivity Commission noted that changes to the law regarding substantiation powers were controversial. The public airing of the ACCC's concerns had inspired strong submissions against empowering the regulatory agency further. ${ }^{30}$ Nevertheless, in the end the Commission considered it desirable to bring the substantiation powers into the Australian law. ${ }^{31}$

Accordingly, when the Australian Consumer Law (ACL) was enacted, it empowered the ACCC to issue substantiation notices to persons in trade. ${ }^{32}$ The period for compliance with the notice is 21 days, although an application for an extension of time

\footnotetext{
27 The author expects that regulatory agencies would vigorously defend their right to be frugal.

28 Australian Government Productivity Commission Review of Australia's Consumer Policy

Framework: Productivity Commission Inquiry Report (30 April 2008).

29 At 243.

$30 \quad$ At 244.

31 At 245.

32 Competition and Consumer Act 2010 (Cth), s 219.
} 
may be made. ${ }^{33}$ It is an offence to refuse or fail to comply with a notice, ${ }^{34}$ and an offence to provide false or misleading information in response. ${ }^{35}$ Both offences attract pecuniary penalties, with the latter attracting the higher penalty: $\$ 27,500$ for a body corporate and $\$ 5,500$ for an individual.

Several factors should be noted here. First, the substantiation notice approach brought in by the ACL sought to respond to the ACCC's concerns about information asymmetry vis-à-vis traders, the scope of their information-gathering powers and the difficulty of prosecuting misrepresentation actions. Secondly, the substantiation notices were considered to be "a preliminary investigative tool that helps the ACCC determine whether further investigation is warranted." 36 Thirdly, through the operation of the notice process, and with the ability to apply for an extension of time for compliance, traders issued with substantiation notices are able to substantiate any claim or representation that they have made retrospectively. The focus of the Australian approach therefore appears to be primarily on addressing the information asymmetry and providing the ACCC with further investigative powers.

To illustrate the application of this approach, if the facts of the Probitas case arose today in Australia, Mr Campbell would be required to produce evidence capable of backing up his fertiliser claims. If he did so, the investigation would stop there. However, if it was apparent that he had no basis for the claims, the ACCC would still need to decide whether to pursue further action under the misrepresentation or misleading conduct provisions. The fact that $\mathrm{Mr}$ Campbell was unable to point to any evidence capable of substantiating his claims may be of some use to the ACCC in bringing those proceedings. Crucially, however, the burden of proof would still rest with the ACCC.

While the New Zealand reforms started off with similar objectives to the Australian approach, it will become apparent that they have strayed a long way since.

Section 220(1).

Section 205.

Section 206.

Ministry of Consumer Affairs, above n 6, at 36. 


\section{Changing Tack-Moving Toward a Prohibition}

\section{A Consumer Law Reform: a Discussion Paper}

\section{$1 \quad$ The reform proposal}

It will be recalled that the in the last discussion paper, a fiscally motivated Ministry proposed that amendments to the FTA should include the power to issue substantiation notices. The next discussion paper was released in June $2010 .{ }^{37}$ At that time the unified Australian provisions were brand new, having been brought into effect in April of that year. ${ }^{38}$ The paper ostensibly marked a return to the familiar consumer confidence focus. In the Foreword, Hon Heather Roy, Minister of Consumer Affairs, stated: ${ }^{39}$

Consumer legislation is an important contributor to consumer confidence and successful consumer participation in the market place. Consumers transacting with confidence contribute to a productive and innovative economy. For businesses, effective consumer laws help to create a competitive business environment where reputable suppliers are protected from the inappropriate market conduct of competitors.

After summarising the current state of the fair trading law in New Zealand, the paper noted that consumer protection legislation should provide protections against "unfair commercial practices". ${ }^{40}$ Foreshadowing the direction that the discussion was to take, the paper noted that "[making] claims which cannot be substantiated" was an example of an unfair commercial practice. ${ }^{41}$

The paper also discussed the manner in which fair trading law is enforced: ${ }^{42}$

Public enforcement involves punitive sanctions (fines) where there is a perceived public harm or an offence rather than individual "private" harms.

\footnotetext{
37 Ministry of Consumer Affairs, above n 6.

38 Trade Practices Amendment (Australian Consumer Law) Act (No. 1) 2010 (Cth), s 2.

39 At 4.

$40 \quad$ At 19.

41 At 20.

42 At 21.
} 
There is usually some moral wrongdoing underpinning offences enforceable by regulators under consumer laws, and enforcement is technically through the courts' criminal jurisdiction.

Unsubstantiated representations were then addressed directly, and it is here that the pivotal departure in approach was made.

The paper started out by noting the general importance of ensuring the veracity of information that is provided to consumers. This was said to be an especially important consideration in the case of "credence goods", or goods whose utility it is difficult or impossible for consumers to ascertain. ${ }^{43} \mathrm{Mr}$ Campbell's organic fertiliser mentioned above is one example of a credence good.

The discussion paper then noted that the FTA did not allow the Commerce Commission to require traders to substantiate their claims. ${ }^{44}$ The paper also stated that the practice of making unsubstantiated claims appeared to be a live issue, particularly in identified "growth areas" of the market, such as "eco-friendliness" and "sustainability". ${ }^{4}$

The paper then addressed the question of whether the FTA ought to be amended to include substantiation provisions similar to the ACL framework. It was accepted that harmonising the law was a logical step toward pursuing the Government's SEM agenda, ${ }^{46}$ but it was argued that adopting substantiation notices would likely be a prima facie breach of the New Zealand Bill of Rights Act 1990. The argument, according to the Ministry, was that substantiation notices reverse the onus of proof, requiring the trader to "prove their innocence".

One solution to this issue, according to the paper, was to create a general prohibition of unsubstantiated representations instead. The paper then offered a draft provision: ${ }^{47}$

No person shall, in trade, make a material claim in relation to the supply or possible supply of goods or services as to the nature, characteristic, or suitability for a purpose

\footnotetext{
$43 \quad$ At 35.

$44 \quad$ At 35 .

$45 \quad$ At 35 .

46 It will be recalled that harmonising the regulatory requirements between Australia and New Zealand was considered to be an important step in facilitating the operation of trans-Tasman markets. 
of those goods or services, without having reasonable grounds to justify or substantiate the claim.

To answer the question "Why a general prohibition?", the paper argued that it would effectively fast track the Commerce Commission's ability to investigate suspected unsubstantiated claims. It was considered that the provision would most often be used "as a wake-up call, rather than as a full-blown prosecution". ${ }^{48}$ The paper further argued that a general prohibition was desirable because there existed a "fundamental premise that honest business should only make supported and justified claims." 49

On the question of penalties, it was argued that the same penalties that apply to misrepresentations ought to apply to the new offence. ${ }^{50}$

\section{Costs and benefits}

The costs and benefits of adopting a prohibition were then assessed. In terms of costs it was considered that, first, there would be compliance costs on businesses in forcing them to have supporting evidence for their claims; secondly, there may be uncertainty as to what constitutes reasonable grounds to substantiate any claim made by a retailer; and thirdly, traders might seek to avoid potential liability by not making any claims at all of their products. ${ }^{51}$ This latter cost was downplayed by the Ministry. They considered it to be "clear" that traders considered the "benefits of making claims" to outweigh "the costs of having to prove [them]", 52

On the other hand, the claimed benefits were multiple. First, it was argued that a prohibition of unsubstantiated representations might have a flow on effect in promoting caution among traders and thereby reducing the chances that they will engage in misleading or deceptive conduct. ${ }^{53}$ Secondly, it was argued that such a prohibition would protect "vulnerable consumers", such as the chronically ill who are targeted by bogus

$\begin{array}{ll}48 & \text { At } 38 . \\ 49 & \text { At } 38 . \\ 50 & \text { At 39. } \\ 51 & \text { At 39. } \\ 52 & \text { At } 40 . \\ 53 & \text { At 39. }\end{array}$


miracle cures. ${ }^{54}$ Thirdly, it was stated that a strict liability offence for failing to substantiate a claim would allow for expedient resolution of any breach. ${ }^{55}$

Finally, the Ministry tapped back into familiar justifications for regulating deceptive and misleading conduct by arguing that the provision would protect honest business and increase the credibility of market places by forcing supporting evidence to be provided to consumers. ${ }^{56}$

\section{An additional paper: substantiation}

Five months later, the Ministry released a further discussion paper dealing specifically with the issue of "substantiation". ${ }^{57}$ By this point, the legal developments were steered firmly toward an outright prohibition, rather than a substantiation notice approach. The additional paper nevertheless discussed both. The objective of the paper was to analyse the proposed amendments further, within a discussion of the existing fair trading legislation.

The "essential question", according to the paper was "whether the rights and remedies available to the Commerce Commission to enforce the strict liability misrepresentation offences under section 13 [were] sufficient to protect consumers and other honest traders, or whether additional rights and remedies [were] necessary." 58 In short, it was considered that existing provisions were insufficient. However whether that answer justified the eventual form of $\mathrm{s} 12 \mathrm{~A}$ is an issue that merits close examination.

The paper noted that submissions received on the previous discussion paper had demonstrated widespread support for the adoption of a general prohibition. ${ }^{59}$ A rather simple idea underlined this support: "[It is] dishonest for suppliers and manufacturers to sell goods or services if they cannot substantiate the claims they make." ${ }^{60}$ This marked a subtle shift in the policy of the amendments. It was now considered that making claims

\footnotetext{
At 39 .

At 39 .

At 39 .

Ministry of Consumer Affairs Consumer Law Reform Additional Paper: Substantiation (November 2010).

At 2 .

At 3 .

Ministry of Consumer Affairs, above n 57, at 3.
} 
without any evidence to back them up was, in itself, inappropriate market behaviour that ought to be proscribed.

\section{B The End Result - Section $12 \mathrm{~A}$}

The general prohibition found its way into the Consumer Law Reform Bill, introduced in April 2011 under the Consumer Affairs portfolio. From this Bill, the Fair Trading Amendment Act 2013 was eventually carved out. Section 10 inserted the new prohibition into Part 1 of the FTA. The result is that New Zealand has created a general prohibition of unsubstantiated representations in trade, which came into force on 17 June $2014:^{61}$

\section{A Unsubstantiated representations}

(1) A person must not, in trade, make an unsubstantiated representation.

(2) A representation is unsubstantiated if the person making the representation does not, when the representation is made, have reasonable grounds for the representation, irrespective of whether the representation is false or misleading.

(3) This section does not apply to a representation that a reasonable person would not expect to be substantiated.

(4) In this section and sections $12 \mathrm{~B}$ to $12 \mathrm{D}$, representation means a representation that is made-

(a) in respect of goods, services, or an interest in land; and

(b) in connection with-

(i) the supply or possible supply of the goods or services; or

(ii) the sale or grant or possible sale or grant of the interest in land; or

(iii) the promotion by any means of the supply or use of the goods or services or the sale or grant of the interest in land.

\section{B Court must have regard to certain matters}

(1) In proceedings concerning a contravention of section $12 \mathrm{~A}$, and in assessing whether a person had reasonable grounds for a representation, a court must have regard to all of the circumstances, including-

(a) the nature of the goods, services, or interest in land in respect of which the representation was made:

61 Fair Trading Amendment Act 2013, s 2(2). 
(b) the nature of the representation (for example, whether it was a representation about quality or quantity):

(c) any research or other steps taken by or on behalf of the person before the person made the representation:

(d) the nature and source of any information that the person relied on to make the representation:

(e) the extent to which the person making the representation complied with the requirements of any standards, codes, or practices relating to the grounds on which such a representation may be made, and the nature of those requirements:

(f) the actual or potential effects of the representation on any person.

The prohibition was not significantly different from the Ministry's initial vision. "Representation" carries the same meaning as in the false or misleading representation provisions. Contravention attracts maximum penalties of $\$ 200,000$, in the case of an individual, and $\$ 600,000$, in the case of a body corporate. ${ }^{62}$

However, it did receive some sensible revisions along the way. Section $12 \mathrm{~A}(3)$ is designed to provide that "puffery" 63 is not caught by the prohibition. Section 12B provides for mitigating considerations such as reasonable reliance on existing research, ${ }^{64}$ compliance with any existing industry codes of practice, ${ }^{65}$ and the "potential effects" of the representation. ${ }^{66}$

The key change in the law brought about by these provisions is that a person in trade may now be held liable for making a representation that is eventually proved to be true. Section $12 \mathrm{~A}$ is a strict liability offence, and, in contrast with the Australian provisions, there is no room for retrospective application of evidence that might substantiate the claim. The best that a defendant can hope for if charged with making an unsubstantiated representation that turns out to be true is that the penalty might be reduced pursuant to $\mathrm{s} 12 \mathrm{~B}(1)(\mathrm{f})$ above.

Fair Trading Act 1986, s 40(1)(a).

63 "Whiter than white" and similar hyperbolic marketing claims.

64 Section $12 B(1)(d)$.

65 Section $12 \mathrm{~B}(1)(\mathrm{e})$.

66 Section $12 \mathrm{~B}(1)(\mathrm{f})$. 
Clearly, the extent of liability that was contained in the false or misleading representation provisions has been significantly widened by the amendments.

\section{Discussion}

\section{A The Deficiency of Misrepresentations}

Why did the Ministry consider the existing fair trading provisions to be inadequate? Two reasons had thus far been given.

First, it was argued that it was difficult for the Commerce Commission to take positive action against unsubstantiated representations. ${ }^{67}$ The reasons for this are discussed above, but the essential point is that under the existing provisions, whatever the level of evidence relied upon by the trader, the Commission must adduce sufficient evidence to prove that the claim was in fact false or misleading. A closely related concern was that this requirement imposes significant costs on the Commission.

Secondly, while the Commission has information-gathering powers under s $47 \mathrm{G}$ of the FTA, it had argued that these powers were insufficient on the basis that the case law had given them a restrictive interpretation. ${ }^{68}$

The case cited in support of the latter claim was Telecom Corporation of New Zealand Ltd $v$ Commerce Commission. ${ }^{69}$ In the Telecom case, the court said that "[the Commission] has power to seek information only where it is relevant to the investigation, which itself must be one authorised by the Act." 70

The Commission's claim that the Telecom case gave the $\mathrm{s} 47 \mathrm{G}$ powers a restrictive interpretation is unconvincing. It can hardly be said that it would be difficult to demonstrate a degree of relevance between a false or misleading representation investigation and a request for documents capable of substantiating the impugned claim. If such documents exist, there are no grounds for bringing the charges. Furthermore, in

\footnotetext{
67 Ministry of Consumer Affairs, above n 6, at 35; Ministry of Consumer Affairs, above n 57, at 2.

68 Ministry of Consumer Affairs, above n 6, at 37.

69 Telecom Corporation of New Zealand Ltd v Commerce Commission [1991] NZAR 155.

70 At 162. The case concerned the Commission's powers under s 98 of the Commerce Act 1986, which mirrored those found in $\mathrm{s} 47 \mathrm{G}$ of the FTA.
} 
the case itself, Gallen J stated that "in an investigative situation and in the context of the section, the onus [to show a degree of relevance] must be a very easy one to discharge.""71

Interestingly, in their submission to the Select Committee on the Consumer Law Reform Bill, the Commerce Commission accepted that the powers under s $47 \mathrm{G}$ were sufficient to request documents capable of substantiating the claim. ${ }^{72}$ However they argued that if a trader was unable to substantiate the claim, a full investigation would nevertheless have to be launched.

Therefore, the only argument left standing is that it was difficult for the Commission to demonstrate that an unsubstantiated representation contravened the existing provisions of the FTA.

It will be recalled from the discussion of the case of Esso Petroleum Co Ltd $v$ Mardon above that a claim may, in some circumstances, contain an implied statement of fact that there were reasonable grounds to believe it was true. In a submission to the Select Committee on the Consumer Law Reform Bill, Meridian Energy cited a line of authority that employed reasoning similar to that in Esso, and concluded that "where the absence of reasonable grounds is itself misleading, the FTA already applies." 73 Therefore, it was argued that the existing provisions were capable of capturing unsubstantiated representations.

Accordingly, the Commission's real complaint seemed to be that it was too expensive to adduce sufficient evidence to establish a contravention of the existing provisions. This objection is understandable. The burden of proof that rests on the Commission is significant. When the Commission has difficulty ascertaining whether there are reasonable grounds for a claim that is made, launching a full investigation must seem an unattractive option. However, that does not necessarily lead to the conclusion that a prohibition on making unsubstantiated representations was the appropriate response.

At 163 .

Commerce Commission "Submission on the Consumer Law Reform Bill" at [68].

Meridian Energy Ltd “Meridian's Submission on the Consumer Law Reform Bill to the Commerce Select Committee" at [23]. 


\section{B Were Substantiation Notices Sufficient?}

The initial intention of the consumer law reform was to adopt the substantiation notice approach. As mentioned above, this approach was abandoned in favour of a general prohibition. It will be shown that that decision was based on flawed reasoning. However, before addressing that issue, it will be argued that a substantiation notice approach was capable of satisfying the objectives of the consumer law reform process.

First, it will be recalled that the substantiation notice powers were enacted in Australia in response to concerns expressed by the Australian regulatory agency that mirrored those of the Commerce Commission. Australia did not consider it necessary to go further and create a general prohibition, and there is nothing in the consumer law reform discussion documents to suggest that the Australian approach was ineffective. On the contrary, the additional paper on substantiation noted that following the ACL enactment, "lawyers [were] advising their clients to hold credible and complete information substantiating any claims they make from the time those claims are made."74

Secondly, the New Zealand Law Society argued that s 12A would require businesses that conduct trans-Tasman operations to comply with more stringent regulatory requirements in New Zealand than in Australia. ${ }^{75}$ As mentioned above, s 12A significantly widens the extent of liability. In particular, traders are unable to substantiate their claims retrospectively under a prohibition approach. Consequently, businesses that conduct trans-Tasman operations are forced to comply with more strict regulatory standards in order to gain access to a smaller market. This seems antithetical to the Government's SEM agenda. By contrast, adopting substantiation notices would have harmonised the regulatory requirements and thus promoted the agenda.

Thirdly, the substantiation notice approach is more consistent with the preliminary consumer law reform discussions. It will be recalled that an initial justification for adopting substantiation provisions in New Zealand was to address the perceived gap in "mid-level" enforcement tools. The Commission was concerned about increasing costs and the proliferation of litigation under the FTA.

\footnotetext{
$74 \quad$ Ministry of Consumer Affairs, above n 57, at 9.

75 New Zealand Law Society "Submission on the Consumer Law Reform Bill” at [29].
} 
Furthermore, the preliminary reform discussions stated that an effective model for securing compliance with the legislation should allow the regulatory agency to initially engage methods that persuade the trader to comply, while retaining the ability to escalate the sanctions if necessary.

The substantiation notice approach achieves those objectives. By requiring a trader to provide substantiating evidence, the Commission would first establish whether the claims are valid. If the claims appeared to be unsubstantiated, the Commission could persuade the trader to cease making the claims. This would be backed up by the ability to initiate proceedings under the existing misleading or deceptive conduct provisions of the FTA, should the trader refuse to comply.

By contrast, a general prohibition approach might be described as a "high-level" enforcement tool. Section 12A does not address the perceived gap of mid-level enforcement tools, but rather creates a new source of litigation. Accordingly, taking action under the provision amounts to "escalating the sanctions" from the beginning. This is inconsistent with the "effective model" for securing compliance previously endorsed by the Ministry.

Accordingly, it is argued that adopting a substantiation notice approach would have been a logical step in the consumer law reform process, and that going further was unnecessary. A similar argument was raised by the Law Society. In their submission to the Select Committee, the Society contended that "the scope of [s 12A was] too broad", and recommended that it be "reconsidered, and aligned with the Australian provisions." 76

\section{Why Did New Zealand Go Further?}

It was mentioned briefly above that the initial decision to favour a prohibition was due to the impression that a substantiation notice approach would amount to a "reverse onus" in breach of the Bill of Rights Act $1990 .{ }^{77}$ It appears that the fallacy of this argument was realised soon after, as the Ministry later accepted that no such issue arose on a substantiation notice approach. ${ }^{78}$ Nevertheless, it is worth addressing the argument for two reasons.

\footnotetext{
76 New Zealand Law Society, above n 75, at [32].

77 Specifically, the right to be presumed innocent in s 25(c).

78 Ministry of Consumer Affairs, above n 57, at 13.
} 
First, it was this argument that caused the Ministry to "change tack" toward a prohibition approach. ${ }^{79}$ Secondly, it resurfaced in the Ministry's advice to the Select Committee on the Consumer Law Reform Bill. ${ }^{80}$ The Ministry noted that the Australian approach had been considered, but stated that a prohibition was preferable since it "[would avoid] the strong reverse onus that ... substantiation notices would impose." 81

The Bill of Rights argument can be dispensed with in short order. Substantiation notices are simply a preliminary investigative tool, and the engagement of criminal procedure rights is only a live issue once charges have actually been filed. ${ }^{82}$ Furthermore, whatever information is provided in response to a substantiation notice, the onus remains on the prosecuting party. They must still demonstrate, to the required standard of proof, that the representation was in fact false or misleading. Guilt will not be presumed.

\section{Intrinsic Validity}

It has been argued that the substantiation notice approach would have achieved the objectives of the consumer law reform process. It has also been argued that the decision to move toward a general prohibition approach was based on flawed reasoning. Nevertheless, before a conclusion on the validity of s $12 \mathrm{~A}$ can be reached, it is necessary to assess whether it can be justified on its own merits.

It will be recalled that the guiding principle for the consumer law reforms was the desire to foster consumer confidence. The Ministry asked whether that confidence was compromised by the fact that traders could make representations for which they had no reasonable grounds. ${ }^{84}$ It was noted that such conduct was difficult to bring within the ambit of the existing misrepresentation provisions, due to the information asymmetry issue discussed above.

The Ministry accepted that two ways of dealing with this issue were to address the information imbalance, or to prohibit the behaviour from the outset. Ultimately, it

\footnotetext{
79 Ministry of Consumer Affairs, above n 6, at 37.

80 Ministry of Consumer Affairs Briefing for the Commerce Committee on the Consumer Law Reform Bill (27 March 2012).

81 At [39].

82 The opening words of s 25 of the Bill of Rights Act 1990 are "[e]verybody who is charged with an offence" (emphasis added). 
favoured the latter approach, claiming that "[t]he intention of such a provision would be to incentivise traders to make sure they can substantiate any claims they make before they make the claim." 85 It considered this to be a market behaviour issue, closely tied to considerations of consumer confidence.

While prohibiting the behaviour may well lead to consumer confidence, the problem with this argument is that it nevertheless fails to demonstrate necessity. While the Ministry criticised substantiation notices as a "limited procedural response", 86 it did not explain why a limited response was inadequate. If it is accepted that the substantiation notice approach was in fact capable of achieving the objectives of the consumer law reform process, it is submitted that going further should have been accompanied by compelling justification.

A recurring criticism levelled at $\mathrm{s} 12 \mathrm{~A}$ in the various submissions to the Select Committee was that it unnecessarily widened the extent of liability under the FTA. Westpac New Zealand argued that: ${ }^{87}$

The prohibition provides no additional protection to the public under the FTA as no harm can occur from true and accurate representations, and if the representation is false or misleading, there is already adequate protection in the FTA to deal with the situation.

Similarly, Meridian Energy considered that the only situation caught by s $12 \mathrm{~A}$ that is not already caught by the FTA was an unsubstantiated representation that turned out to be true. ${ }^{88}$ Meridian stated that they were "unable to understand the policy basis for criminalising such claims, particularly considering that they do not harm consumers." 89

85 Ministry of Consumer Affairs, above $\mathrm{n} 57$, at 6 (emphasis in original).

Ministry of Consumer Affairs Regulatory Impact Statement: Consumer Law Reform (July 2010), at 16.

87 Westpac New Zealand Ltd "Submission to Commerce Select Committee: Consumer Law Reform Bill", at [5.1].

88 Meridian, above $\mathrm{n}$ 73, at [23].

89 At [24]. 
Contact Energy also argued that the existing provisions of the FTA were sufficient, ${ }^{90}$ and added that:

[R]elying on the general prohibition on false or misleading statements to regulate unsubstantiated representations is more consistent with the Government's stated commitment of introducing "new regulation only when [it] is satisfied that it is required, reasonable, and robust".

The Select Committee report on the Bill argued that: ${ }^{91}$

No direct harm may necessarily occur from representations that are true but nonetheless unsubstantiated, but there can be indirect harm. Traders who incur the costs of undertaking relevant research before making claims are disadvantaged relative to traders willing to make unsubstantiated claims. There can also be indirect harm to consumers, such as paying a premium for goods when additional benefits are not substantiated, or buying goods in the expectation they will deliver particular outcomes that are not substantiated.

It may be true that traders who undertake research to verify their claims are disadvantaged relative to unscrupulous traders. However, it is questionable whether this alone justifies extending liability, and the significant consequent penalties, to situations where it is proved that no direct harm has occurred.

Furthermore, it was not shown that the substantiation notice approach was inadequate to address the "indirect harm". Traders who do undertake research would not be disadvantaged under a substantiation notice framework because they would be able to respond quickly to any substantiation notice served on them, whereas unscrupulous traders would not. Accordingly, in the absence of an explanation as to why the substantiation notice approach was insufficient and why a prohibition was necessary, there is a very real risk that $\mathrm{s} 12 \mathrm{~A}$ amounts to "regulatory overreach". ${ }^{92}$

Having arrived at that conclusion, it is difficult to resist the inference that the primary motivation for s $12 \mathrm{~A}$ was to shift the onus of proving the validity of claims from the Commerce Commission onto the defendant. Although the Ministry argued that the

\footnotetext{
90 Contact Energy Ltd "Consumer Law Reform Bill: Submission to Commerce Committee” at [2.1].

91 Consumer Law Reform Bill 2011 (287-2) (select committee report) at 3.

92 Meridian, above $\mathrm{n} 73$, at [24].
} 
prohibition approach does not technically amount to a reverse onus, ${ }^{93}$ in practice it will come very close.

Thus, suppose once more that the facts of Probitas arose today, and that the Commission launched an investigation against Mr Campbell under s 12A. Pursuant to the information-gathering powers under s $47 \mathrm{G}$, the Commission could effectively require him to substantiate his extravagant fertiliser claims. When it was apparent that he could not, proceedings would presumably issue. However, as a result of the enactment of s 12A, all the Commission would need to prove is that Mr Campbell had no reasonable grounds for the various claims he had made.

Given that the extent of the evidence adduced by Mr Campbell at trial was the testimony of his "Southland agent" as to the performance of his own farm, ${ }^{94}$ the evidential hurdle confronting the Commission would be considerably lower. Indeed, apart from pointing to the fact that $\mathrm{Mr}$ Campbell was unable to provide any evidence in response to the $\mathrm{s} 47 \mathrm{G}$ notice, it is difficult to imagine what more the Commission would actually need to prove in order to successfully bring the charge.

\section{Conclusion}

The Ministry's review of New Zealand's consumer protection laws highlighted the problem that it was difficult for the Commerce Commission to bring unsubstantiated representations within the scope of the existing FTA provisions. Two reasons for this emerged. First, an information asymmetry issue existed between traders and the Commission. Secondly, bringing proceedings under the misrepresentation provisions imposed significant costs on the Commission.

The Ministry initially argued for an amendment to the FTA that would allow the Commerce Commission to issue substantiation notices. This was the approach taken by Australia in response to similar concerns voiced by their own regulatory agency. This approach would have addressed the information asymmetry issue, and would have coincided with the underlying objectives of the consumer law reform process.

Instead, New Zealand opted to create a general prohibition. Initially, this was based on the misconception that a substantiation notice approach would breach the Bill of

93 Ministry of Consumer Affairs, above n 57, at 12.

94 Probitas, above n 13, at [92]. 
Rights Act. However, by the time the fallacy of that argument was realised the reforms were steered firmly toward a general prohibition.

The failure to demonstrate the deficiency of alternative approaches allowed the inference to be drawn that the real motivation for creating a prohibition was to shift the cost of substantiating claims from the Commerce Commission onto traders. Since s 12A significantly widened the previous limits of liability under the FTA without a convincing justification for doing so, it is concluded that the amendment was an unsubstantiated reform. 


\section{Bibliography}

\section{A Cases}

$1 \quad$ New Zealand

AstraZeneca Ltd v Commerce Commission [2009] NZSC 92.

Commerce Commission v Probitas Ltd and Ewan Malcolm Campbell DC Tauranga CRN: 05079500275-82, 26 March 2007.

Drew v Attorney-General [2002] 1 NZLR 58.

Red Eagle Corporation Ltd v Ellis [2010] NZSC 20.

Telecom Corporation of New Zealand Ltd v Commerce Commission [1991] NZAR 155.

2 England

Esso Petroleum Co Ltd v Mardon [1975] QB 819.

Esso Petroleum Co Ltd v Mardon [1976] QB 801.

\section{B Legislation}

$1 \quad$ New Zealand

New Zealand Bill of Rights Act 1990.

Commerce Act 1986.

Fair Trading Act 1986.

Fair Trading Amendment Act 2013.

Consumer Law Reform Bill 2011 (287-2).

\section{Australia}

Competition and Consumer Act 2010 (Cth).

Trade Practices Amendment (Australian Consumer Law) Act (No. 1) 2010 (Cth). 


\section{Books and Chapters in Books}

John Burrows, Jeremy Finn and Stephen Todd Law of Contract in New Zealand ( $^{\text {th }}$ ed, LexisNexis, Wellington, 2012).

Lindsay Trotman Misrepresentation and the Fair Trading Act (Dunmore Press, Palmerston North, 1988).

Lindsay Trotman and Debra Wilson Fair Trading: Misleading or Deceptive Conduct (LexisNexis, Wellington, 2006).

\section{Journal Articles}

Raymond Sauer and Keith Leffler "Did the Federal Trade Commission's Advertising Substantiation Program Promote More Credible Advertising?” (1990) 80 TAER 191.

\section{E Parliamentary and Government Materials \\ $1 \quad$ Parliamentary debates}

(9 February 2012) 677 NZPD 283.

(11 December 2012) 686 NZPD 7410.

(3 December 2013) 695 NZPD 15173.

2 Submissions to the Select Committee

Auckland District Law Society Inc "Submissions to the Commerce Select Committee on the Consumer Law Reform Bill”.

ANZ National Bank Ltd "Submission on the Consumer Law Reform Bill”.

Commerce Commission "Submission on the Consumer Law Reform Bill”.

Contact Energy Ltd "Consumer Law Reform Bill: Submission to Commerce Committee". Meridian Energy Ltd "Meridian's Submission on the Consumer Law Reform Bill to the Commerce Select Committee".

New Zealand Law Society "Submission on the Consumer Law Reform Bill”. 
Westpac New Zealand Ltd "Submission to Commerce Select Committee: Consumer Law Reform Bill”.

$3 \quad$ Papers and reports

Australian Government Productivity Commission Review of Australia's Consumer Policy Framework: Productivity Commission Inquiry Report (30 April 2008).

Consumer Law Reform Bill 2011 (287-2) (select committee report).

Ministry of Business, Innovation and Employment Consumer Law Reform Bill - Part 1 Departmental Report: Clauses 1 and 2 and 3 to 31 Amendments to Fair Trading Act 1986 (17 July 2012).

Ministry of Consumer Affairs Briefing for the Commerce Committee on the Consumer Law Reform Bill (27 March 2012).

Ministry of Consumer Affairs Consumer Law Reform: A Discussion Paper (June 2010).

Ministry of Consumer Affairs Consumer Law Reform Additional Paper: Substantiation (November 2010).

Ministry of Consumer Affairs Regulatory Impact Statement: Consumer Law Reform (July 2010).

Ministry of Consumer Affairs Review of the Redress and Enforcement Provisions of Consumer Protection Law: Initial Think Piece (July 2005).

Ministry of Consumer Affairs Review of the Redress and Enforcement Provisions of Consumer Protection Law: International Comparison Discussion Paper (May 2006).

\section{F Other Resources}

Madeleine Kearney "Gone fishin' - ACCC's new power to issue substantiation notices" (13 September 2010) Clayton Utz <www.claytonutz.com>. 
Word Count (excluding footnotes and bibliography): 7,921. 